\title{
New data on the distribution of ladybird beetles (Coleoptera: Coccinellidae) in the eastern part of the Baltic Coast region in Poland
}

\author{
Karol SZAWARYN $^{1}$, Piotr CERYNGIER ${ }^{2}$ and Jerzy ROMANOWSKI ${ }^{2}$ \\ ${ }^{1}$ Department of Invertebrate Zoology and Parasitology, University of Gdańsk, Wita Stwosza 59, 80-308 Gdańsk, \\ e-mail: karol.szawaryn@biol.ug.edu.pl (corresponding author) \\ ${ }^{2}$ Faculty of Biology and Environmental Sciences, Cardinal Stefan Wyszyński University in Warsaw, Wóycickiego 1/3, \\ 01-938Warszawa; e-mails: p.ceryngier@uksw.edu.pl, j.romanowski@uksw.edu.pl
}

\begin{abstract}
New data on the occurrence of ladybird beetles in the eastern part of the Baltic Coast of Poland are presented. Studies were carried out between 2012 and 2017 along the Baltic coast from Krynica Morska to Białogóra. We found 44 species of Coccinellidae. Ten of the recorded species (Clitostethus arcuatus, Scymnus haemorrhoidalis, S. limbatus, S. abietis, S. auritus, S. rubromaculatus, Stethorus pusillus, Hyperaspis concolor, H. reppensis, Platynaspis luteorubra) are reported for the first time from the investigated area. Two of them, C. arcuatus and S. pusillus, are new for the whole Baltic Coast region of Poland. The recorded contribution of the invasive Harmonia axyridis to all ladybird individuals was relatively low (12.7\%).
\end{abstract}

Key words: Clitostethus arcuatus, Harmonia axyridis, faunistics, new records

\section{INTRODUCTION}

Owing to a few common species, the ladybirds (Coleoptera: Coccinellidae) are a relatively well recognized beetle group. However, knowledge on the distribution of individual species in Poland is rather fragmentary. Until recently, the main source of faunistic data on Polish ladybirds were papers by Bielawski published between 1955 and 1981 (Bielawski 1955, 1958, 1959, 1961, 1962, 1971, 1978, Czechowska \& Bielawski 1981). Many of these papers are of a regional scope (Bieszczady Mts, Pieniny Mts, Warsaw and Mazovia). Moreover, several important changes in the systematics of Coccinellidae were recently made (Fürsch et al. 1967, Ślipiński 2007), which in some cases makes the older data on the distribution of some species (e.g. of the genera Scymnus and Hyperaspis) doubtful or requiring verification. There are still many areas in Poland with a very incomplete recognition of the ladybird fauna. Recently, several papers partially filling these gaps were published, providing data from various regions in Poland (Ruta et al. 2009, Greń et al. 2013, Jędryczkowski \& Gutowski 2014, Borowski 2015, Ceryngier et al. 2015, 2016a, 2016b, Szczepański et al. 2015).

Although Coccinellidae have never been an object of regular faunistic research in the Baltic Sea coastal area in Poland, scattered data on their distribution in this region can be found in numerous publications. Many data are included in old papers by German (e.g. Lentz 1866, 1879; Brischke 1888, 1891, Lüllwitz 1914, 1915, Kleine 1940) and Polish authors (Węgrzecki 1932, Bartoszyński 1937). Some species very rare in Poland, e.g. Ceratomegilla undecimnotata (Schneider, 1792), Hyperaspis reppensis (Herbst, 1783), Novius cruentatus (Mulsant, 1846), Parexochomus nigromaculatus (Goeze, 1777) or Scymnus apetzi Mulsant, 1846, were mentioned in those papers. These data, however, are often difficult to verify today. More recent publications (e.g. Jędrzejczak 2002, Konopko \& Wilga 2014; Bloch-Orłowska et al. 2015) mostly mention common species, but rare species, such as Calvia quindecimguttata (Fabricius, 1777) (Bubienko \& Ciepielewska 2010), Cynegetis impunctata (Linnaeus, 1767) 
(Bielawski 1962, Napiontek \& Szawaryn 2017), Hippodamia septemmaculata (De Geer, 1775) (Wolender \& Zych 2007), P. nigromaculatus (Konopko et al. 2017), Scymnus schmidti Fürsch, 1958 (Wojas 2017), or a species completely unexpected in this region, Ceratomegilla alpina (Villa \& Villa, 1835) (Śliwiński \& Kowalczyk 1995), are also reported.

In this paper we present new data on the distribution and relative abundance of the members of Coccinellidae in the eastern part of the Baltic Sea coast in Poland, from the Vistula Spit in the east to the surroundings of the village Białogóra in the west.

\section{STUDY AREA, MATERIAL AND METHODS}

The area of our survey covers the eastern part of the region distinguished in the Catalogus faunae Poloniae (Katalog fauny Polski) (Burakowski et al. 1986) as the Baltic Coast (Pobrzeże Bałtyku). The names and territorial limits of other regions in Poland mentioned in this paper also follow the regionalization used in that publication.

Data presented in the paper come from the following localities within individual $10 \mathrm{~km} \mathrm{x}$ $10 \mathrm{~km}$ grid coordinates (shown in Fig. 1):

UTM zone 33U: XA97 - Białogóra;

UTM zone 34U: CF07 - Wierzchucino; CF17 - Dębki, Krokowa, Odargowo, Pustki, Szary Dwór, Żarnowiec; CF27 - Jastrzębia Góra, Karwia; CF33 - Gdynia Wielki Kack; CF35 Mechelinki; CF37 - Chłapowo, Władysławowo; CF42 - Gdańsk VII-Dwór; CF43 - Gdańsk Przymorze; CF44 - Gdynia Śródmieście; CF46 - Kuźnica; CF47 - Chałupy; CF52 - GdańskGórki Wschodnie; CF55 - Hel; CF56 - Jurata; CF62 - Gdańsk-Świbno; CF92 - Krynica Morska.

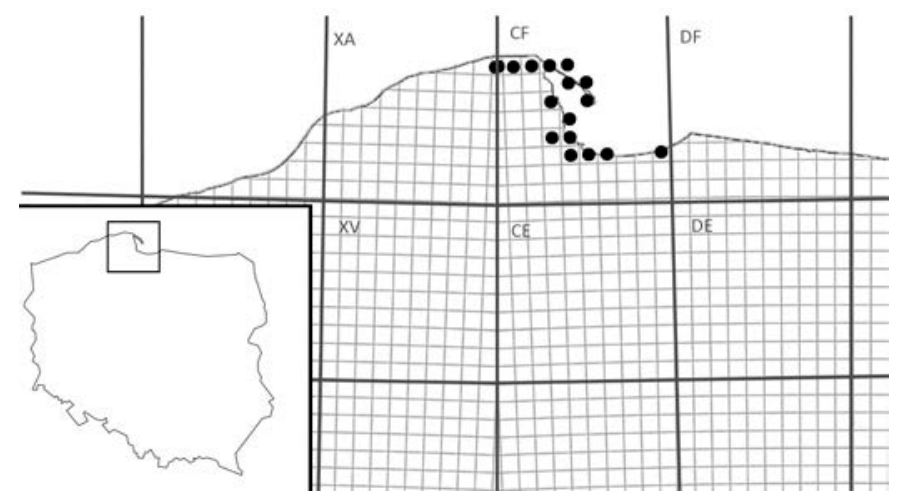

Fig. 1. A map showing $10 \mathrm{~km} \times 10 \mathrm{~km}$ grid coordinates, in which samples of Coccinellidae for this study were collected.

We sampled Coccinellidae during field trips made in growing seasons between 2012 and 2017. Additionally, we used materials collected in 2017 by the students of the University of Gdańsk during their field course on Sobieszewo Island (localities: Gdańsk-Górki Wschodnie, Gdańsk-Świbno). Ladybirds were collected in various habitats and from various plants using standard methods of insect catching: sweep netting through low vegetation, shaking insects down from trees and shrubs on a $1 \mathrm{~m} \mathrm{x} 1 \mathrm{~m}$ beating sheet, and picking directly observed individuals. All collected or observed individuals were noted. The majority of them, after being identified, were freed at the place they had been collected. We only took some ladybirds requiring identification in the laboratory and a few individuals of each species serving as 
voucher specimens. They are stored in the authors' collections. Materials collected by students were identified by the first author.

Ladybird species nomenclature used in this paper follows Kovár (2007) and the division of the family into subfamilies and tribes follows Seago et al. (2011) and Escalona et al. (2017).

The following acronyms of the ladybird collectors are used below: JR - Jerzy Romanowski, KS - Karol Szawaryn, MN - Marlena Napiontek, PC - Piotr Ceryngier, SUG students of the University of Gdańsk.

\section{RESULTS}

Altogether, in 2012-2017 we recorded in the investigated area 4471 individuals of Coccinellidae belonging to 44 species (Table 1). Coccinella septempunctata was the species most commonly collected (17.2\% of all recorded ladybirds). Other frequently registered species included the invasive Harmonia axyridis (12.7\%), Propylea quatuordecimpunctata (11.2\%), Psyllobora vigintiduopunctata (7.0\%), Rhyzobius chrysomeloides (6.4\%) and Scymnus suturalis (6.3\%). The list indicating grid coordinates for each of the recorded ladybird species is given in Table 2 .

Table 1. The list of Coccinellidae found in the eastern part of the Baltic Coast in Poland during this study with the number of specimens recorded.

\begin{tabular}{|c|c|c|c|c|}
\hline No. & Coccinellidae: Coccinellinae & imagines & larvae & pupae \\
\hline & Chilocorini & & & \\
\hline 1 & Chilocorus bipustulatus (Linnaeus, 1758) & 11 & 2 & \\
\hline 2 & Chilocorus renipustulatus (Scriba, 1791) & 125 & 10 & 13 \\
\hline \multirow[t]{2}{*}{3} & Exochomus quadripustulatus (Linnaeus, 1758) & 81 & & 1 \\
\hline & Coccidulini & & & \\
\hline 4 & Clitostethus arcuatus (Rossi, 1794) & 1 & & \\
\hline 5 & Coccidula rufa (Herbst, 1783) & 6 & & \\
\hline 6 & Coccidula scutellata (Herbst, 1783) & 1 & & \\
\hline 7 & Rhyzobius chrysomeloides (Herbst, 1783) & 285 & & \\
\hline 8 & Scymnus (Neopullus) haemorrhoidalis Herbst, 1797 & 10 & & \\
\hline 9 & Scymnus (Neopullus) limbatus Stephens, 1832 & 1 & & \\
\hline 10 & Scymnus (Parapullus) abietis (Paykull, 1798) & 1 & & \\
\hline 11 & Scymnus (Pullus) auritus Thunberg, 1795 & 8 & & \\
\hline 12 & Scymnus (Pullus) suturalis Thunberg, 1795 & 279 & 3 & \\
\hline 13 & Scymnus (Scymnus) frontalis (Fabricius, 1787) & 2 & & \\
\hline 14 & Scymnus (Scymnus) nigrinus Kugelann, 1794 & 32 & & \\
\hline 15 & Scymnus (Scymnus) rubromaculatus (Goeze, 1777) & 5 & & \\
\hline 16 & Scymnus (Scymnus) schmidti Fürsch, 1958 & 4 & & \\
\hline \multirow[t]{2}{*}{17} & Stethorus pusillus (Herbst, 1797) & 93 & & \\
\hline & Coccinellini & & & \\
\hline 18 & Adalia bipunctata (Linnaeus, 1758) & 156 & 1 & \\
\hline 19 & Adalia decempunctata (Linnaeus, 1758) & 90 & 1 & \\
\hline 20 & Anatis ocellata (Linnaeus, 1758) & 48 & 1 & \\
\hline 21 & Anisosticta novemdecimpunctata (Linnaeus, 1758) & 3 & & \\
\hline 22 & Aphidecta obliterata (Linnaeus, 1758) & 108 & 3 & \\
\hline 23 & Calvia decemguttata (Linnaeus, 1767) & 26 & 3 & \\
\hline 24 & Calvia quatuordecimguttata (Linnaeus, 1758) & 32 & 2 & \\
\hline 25 & Calvia quindecimguttata (Fabricius, 1777) & 3 & & \\
\hline 26 & Coccinella magnifica Redtenbacher, 1843 & 4 & & \\
\hline 27 & Coccinella quinquepunctata Linnaeus, 1758 & 239 & 1 & \\
\hline 28 & Coccinella septempunctata Linnaeus, 1758 & 759 & 8 & \\
\hline 29 & Coccinula quatuordecimpustulata (Linnaeus, 1758) & 48 & & \\
\hline 30 & Halyzia sedecimguttata (Linnaeus, 1758) & 131 & 1 & \\
\hline 31 & Harmonia axyridis (Pallas, 1773) & 486 & 63 & 21 \\
\hline 32 & Harmonia quadripunctata (Pontoppidan, 1763) & 13 & 2 & \\
\hline
\end{tabular}

Table 1 continued on the next page 
Continuation of the Table 1

\begin{tabular}{|c|c|c|c|c|}
\hline No. & $\begin{array}{l}\text { Coccinellidae: Coccinellinae } \\
\end{array}$ & imagines & larvae & pupae \\
\hline 33 & Hippodamia tredecimpunctata (Linnaeus, 1758) & 25 & & \\
\hline 34 & Hippodamia variegata (Goeze, 1777) & 58 & & \\
\hline 35 & Myrrha octodecimguttata (Linnaeus, 1758) & 24 & & \\
\hline 36 & Myzia oblongoguttata (Linnaeus, 1758) & 8 & & \\
\hline 37 & Propylea quatuordecimpunctata (Linnaeus, 1758) & 491 & 9 & \\
\hline 38 & Psyllobora vigintiduopunctata (Linnaeus, 1758) & 306 & 8 & \\
\hline 39 & Tytthaspis sedecimpunctata (Linnaeus, 1761) & 235 & 2 & \\
\hline & Epilachnini & & & \\
\hline 40 & Cynegetis impunctata (Linnaeus, 1767) & 6 & & \\
\hline 41 & $\begin{array}{l}\text { Subcoccinella vigintiquatuorpunctata (Linnaeus, 1758) } \\
\text { Hyperaspidini }\end{array}$ & 32 & & \\
\hline 42 & Hyperaspis concolor (Suffrian, 1843) & 7 & & \\
\hline 43 & $\begin{array}{l}\text { Hyperaspis reppensis (Herbst, 1783) } \\
\text { Platynaspini }\end{array}$ & 9 & & \\
\hline 44 & Platynaspis luteorubra (Goeze, 1777) & 20 & 4 & \\
\hline & & 4312 & 124 & 35 \\
\hline
\end{tabular}
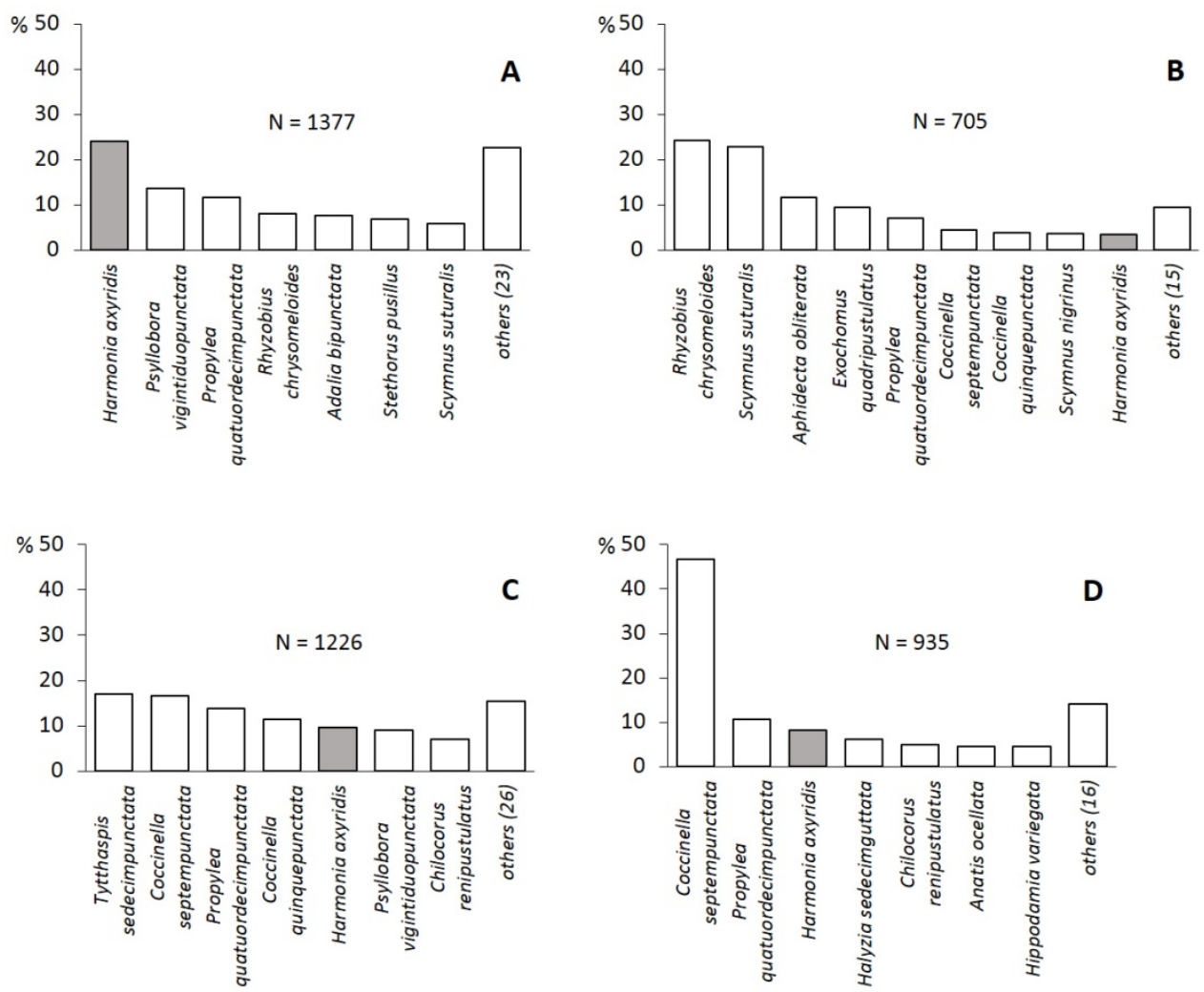

Fig. 2. Species composition of Coccinellidae recorded in the eastern part of the Baltic Coast in Poland on deciduous trees and shrubs (A), conifers (B), herbaceous plants (C) and beaches (D). Filled bars - contribution of the invasive Harmonia axyridis. Records of individuals without indication of the habitat where caught (228 individuals) are omitted in this calculation. 
Table 2. The list of Coccinellidae found in the eastern part of the Baltic Coast in Poland during this study with their records on individual $10 \mathrm{~km} x 10 \mathrm{~km}$ grid coordinates indicated.

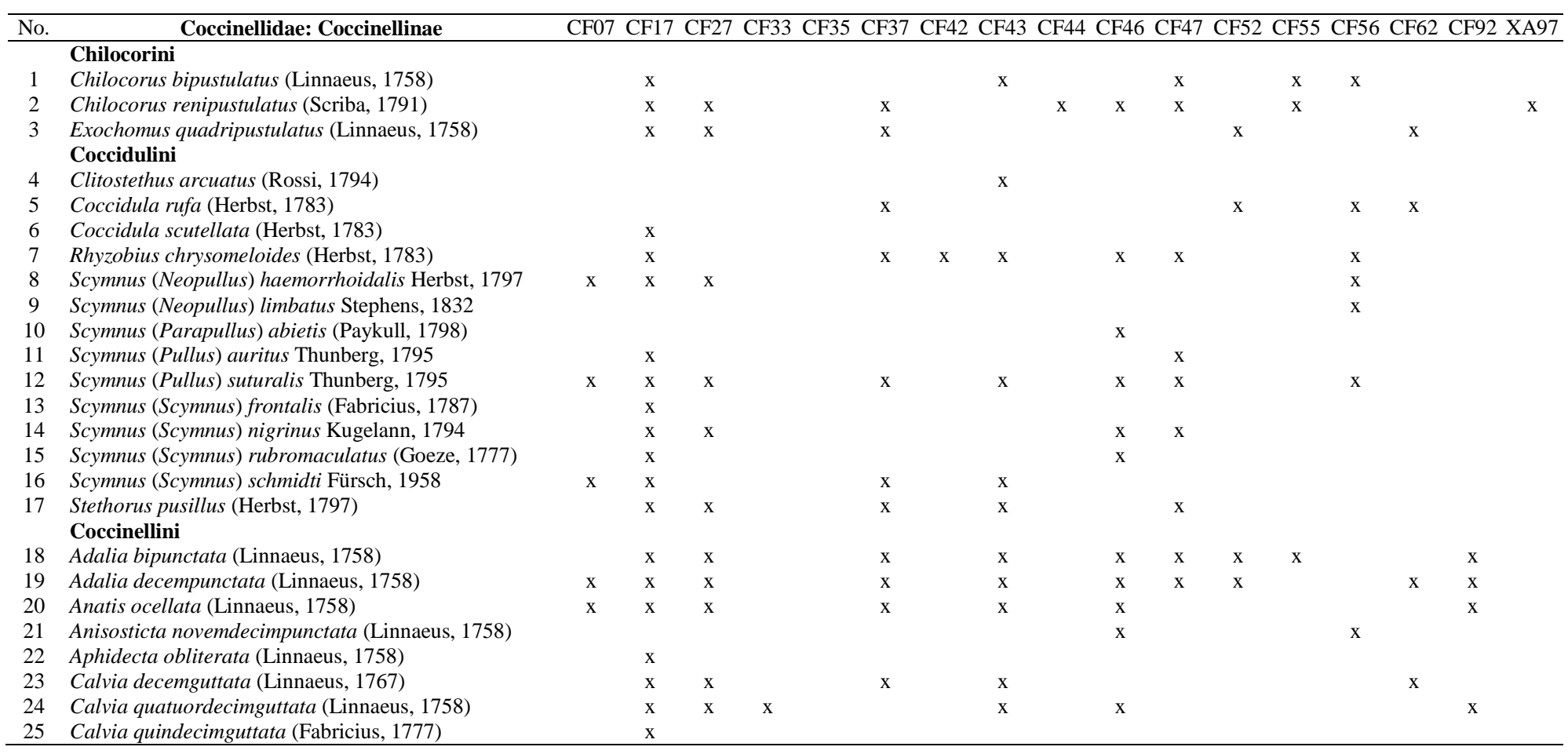


CF07 CF17 CF27 CF33 CF35 CF37 CF42 CF43 CF44 CF46 CF47 CF52 CF55 CF56 CF62 CF92 XA97

26 Coccinella magnifica Redtenbacher, 1843

27 Coccinella quinquepunctata Linnaeus, 1758

28 Coccinella septempunctata Linnaeus, 1758

29 Coccinula quatuordecimpustulata (Linnaeus, 1758)

30 Halyzia sedecimguttata (Linnaeus, 1758)

31 Harmonia axyridis (Pallas, 1773)

32 Harmonia quadripunctata (Pontoppidan, 1763)

33 Hippodamia tredecimpunctata (Linnaeus, 1758)

34 Hippodamia variegata (Goeze, 1777)

35 Myrrha octodecimguttata (Linnaeus, 1758)

36 Myzia oblongoguttata (Linnaeus, 1758)

37 Propylea quatuordecimpunctata (Linnaeus, 1758)

38 Psyllobora vigintiduopunctata (Linnaeus, 1758)

39 Tytthaspis sedecimpunctata (Linnaeus, 1761)

\section{Epilachnini}

40 Cynegetis impunctata (Linnaeus, 1767)

41 Subcoccinella vigintiquatuorpunctata (Linnaeus,

1758)

Hyperaspidini

42 Hyperaspis concolor (Suffrian, 1843)

43 Hyperaspis reppensis (Herbst, 1783)

Platynaspini

\begin{tabular}{|c|c|c|c|c|c|c|c|c|c|c|c|c|c|c|c|}
\hline $\mathrm{X}$ & & & & & & & & & $\mathrm{X}$ & $x$ & & & & & \\
\hline $\mathrm{X}$ & & & & $\mathrm{X}$ & $\mathrm{X}$ & $\mathrm{X}$ & & $\mathrm{x}$ & $\mathrm{x}$ & & $\mathrm{X}$ & $\mathrm{X}$ & $\mathrm{X}$ & $\mathrm{x}$ & $\mathrm{X}$ \\
\hline $\mathrm{X}$ & $\mathrm{X}$ & $\mathrm{X}$ & & $\mathrm{X}$ & $\mathrm{X}$ & $\mathrm{x}$ & & $\mathrm{x}$ & $\mathrm{x}$ & $\mathrm{x}$ & $\mathrm{X}$ & $\mathrm{X}$ & $\mathrm{X}$ & $\mathrm{x}$ & $\mathrm{X}$ \\
\hline $\mathrm{X}$ & $\mathrm{X}$ & & & & & & & & & $\mathrm{x}$ & & & & & \\
\hline $\mathrm{X}$ & $\mathrm{x}$ & & & $\mathrm{X}$ & & $\mathrm{X}$ & & & $\mathrm{X}$ & $\mathrm{x}$ & & & $\mathrm{X}$ & & \\
\hline $\mathrm{X}$ & $\mathrm{X}$ & & $\mathrm{X}$ & $\mathrm{x}$ & & $x$ & $\mathrm{x}$ & $\mathrm{x}$ & $\mathrm{X}$ & & $\mathrm{X}$ & X & & $\mathrm{X}$ & \\
\hline $\mathrm{X}$ & $\mathrm{x}$ & & & $\mathrm{X}$ & & $x$ & & & & & $\mathrm{X}$ & & & $\mathrm{x}$ & \\
\hline $\mathrm{X}$ & $\mathrm{x}$ & & & $\mathrm{X}$ & & & & $\mathrm{X}$ & $\mathrm{X}$ & & & $\mathrm{X}$ & & $\mathrm{x}$ & \\
\hline $\mathrm{x}$ & $\mathrm{X}$ & & $\mathrm{X}$ & $\mathrm{x}$ & & $\mathrm{X}$ & & $\mathrm{x}$ & $\mathrm{x}$ & $\mathrm{x}$ & $\mathrm{X}$ & $\mathrm{x}$ & $\mathrm{X}$ & $\mathrm{x}$ & \\
\hline \multirow[t]{2}{*}{$\mathrm{x}$} & $\mathrm{X}$ & & & & & & & & $\mathrm{x}$ & & & & $\mathrm{x}$ & & \\
\hline & & & & & & $\mathrm{X}$ & & $\mathrm{x}$ & & & & & $\mathrm{x}$ & $\mathrm{X}$ & \\
\hline $\mathrm{X}$ & $\mathrm{X}$ & & & $\mathrm{X}$ & $\mathrm{x}$ & $\mathrm{x}$ & & $\mathrm{x}$ & $\mathrm{x}$ & $\mathrm{x}$ & $\mathrm{X}$ & $\mathrm{X}$ & $\mathrm{x}$ & $\mathrm{x}$ & $\mathrm{x}$ \\
\hline $\mathrm{x}$ & $\mathrm{X}$ & $\mathrm{x}$ & & $\mathrm{X}$ & $x$ & $\mathrm{x}$ & & $\mathrm{x}$ & $\mathrm{x}$ & & & & $\mathrm{x}$ & & $x$ \\
\hline $\mathrm{X}$ & $\mathrm{X}$ & & & $\mathrm{x}$ & & $\mathrm{X}$ & $\mathrm{X}$ & & & $\mathrm{X}$ & & & $\mathrm{X}$ & & \\
\hline
\end{tabular}

$\mathrm{X}$ 
Communities of Coccinellidae found in different vegetation types (deciduous trees and shrubs, coniferous trees and shrubs, and herbaceous plants) and in the areas practically deprived of plant cover (beaches) were clearly different (Fig. 2). On deciduous trees and shrubs the invasive $H$. axyridis was the most common (24\% of individuals caught from these plants), on conifers $R$. chrysomeloides (24.3\%) and S. suturalis $(22.8 \%)$ co-dominated, while on herbaceous plants the co-dominating species were Tytthaspis sedecimpunctata (17\%) and Coccinella septempunctata (16.6\%). On coastal beaches C. septempunctata was distinctly most frequent (46.7\%).

Below we provide detailed data on those species recorded in this study, which have rarely been reported from Poland and/or have not previously been reported from the investigated area. The species new to the eastern part of the Baltic Coast are marked with an asterisk $\left(^{*}\right)$ and new to the whole coastal zone of Baltic Sea in Poland with double asterisk (**).

\section{**Clitostethus arcuatus (Rossi, 1794)}

Material: Gdańsk Przymorze, Ronald Reagan Park (CF43), 1 ex. shaken down from bird cherry (Prunus padus), 29 Apr 2016, leg. JR.

This south European species was reported more than a century ago from Legnica in Lower Silesia (Letzner 1874) and Ojców in Kraków-Wieluń Upland (Eichler 1914), and recently from Upper Silesia (Królik 2006, Greń et al. 2013), Wielkopolska-Kujawy Lowland (Ruta et al. 2009), Pomeranian Lake District (Ceryngier et al. 2016b) and Mazovian Lowland (Bodzon \& Ceryngier 2016, Ceryngier et al. 2016c). Its current range expansion and increase in numbers can probably be attributed to climate change.

\section{Coccidula rufa (Herbst, 1783)}

Material: Jurata (CF56): 3 Aug 2015, 1 ex., leg. JR; 21 Sep 2015, 1 ex. from reed vegetation, leg. JR; Władysławowo (CF37): 21 Sep 2015, 1 ex. from reed vegetation, leg. JR; Gdańsk-Świbno (CF62): 13 Jun 2017, 1 ex., leg. SUG; Gdańsk-Górki Wschodnie (CF52): 17 Jun 2017, 2 exx., leg. SUG.

Widespread in the whole country (Burakowski et al. 1986). In the Baltic Coast reported from Gdańsk (Lentz 1879), Dębki (Enderlein 1908), Hel and Chałupy (Węgrzecki 1932) and Sobieszewo (Burzyński 1971).

\section{Coccidula scutellata (Herbst, 1783)}

Material: Żarnowiec (CF17): 22 Sep 2015, 1 ex., reed vegetation, leg. JR.

Widely distributed in Poland (Burakowski et al. 1986). In the Baltic Coast reported from Pobierowo (Pawłowski 1966), Koszalin (Lüllwitz 1915) and Hel Peninsula (Bartoszyński 1937).

\section{Rhyzobius chrysomeloides (Herbst, 1783)}

Material: Chałupy (CF47): 25 May 2015, 7 exx., leg. JR; 3 Aug 2015, 2 exx., leg JR; 21-26 Sep 2015, 56 exx., leg JR; Dębki (CF17): 17 Aug 2014, 1 ex., leg. JR; 6 Sep 2014, 2 exx., leg. JR; 22-24 May 2015, 9 exx., leg. JR; 27 Jul 2015, 2 exx., leg. JR; 2 Aug 2015, 1 ex., leg. JR; Gdańsk Przymorze, Ronald Reagan Park (CF43): 29 Apr 2016, 6 exx., leg. JR; 21 Jun 2016, 3 exx., leg. JR; Jastrzębia Góra (CF27): 22 Sep 2015, 8 exx., leg. JR; Jurata (CF56): 3 Aug 2015, 2 exx., leg. JR; 22-26 Sep 2015, 20 exx., leg. JR; Odargowo (CF17): 13-16 Aug 2014, 34 exx., leg. JR; 5 Aug 2015, 3 exx., leg. JR; Pustki (CF17): 10-11 Sep 2014, 50 exx., leg. JR; 6-8 Sep 2014, 45 exx., leg. JR; 22-23 May 2015, 3 exx., leg. JR; 
24-25 Jul 2015, 9 exx., leg. JR; 5-7 Aug 2015, 8 exx., leg. JR; Władysławowo (CF37): 1924 Sep 2015, 5 exx., leg. JR; Kuźnica (CF46): 27 Jul 2013, 8 exx., leg. PC; Gdańsk VIIDwór (CF42): 19 May 2017, 1 ex., leg. MN.

Although widespread throughout the country (Burakowski et al. 1986), from the Baltic Coast (Gdynia - Kępa Redłowska) reported only recently as a rare species there (Konopko et al. 2017). Our data demonstrate that in the investigated area $R$. chrysomeloides is a common species.

\section{*Scymnus (Neopullus) haemorrhoidalis Herbst, 1797}

Material: Dębki (CF17): 7 Aug 2014, 1 ex., undergrowth in pine forest, leg. JR; 22 May 2015, 1 ex. on spruce (Picea abies), leg. JR; Jurata (CF56): 3 Aug 2015, 4 exx., psammophilous grassland, leg. JR; Wierzchucino (CF07): 4 Aug 2015, 1 ex., undergrowth in pine forest, leg. JR; Pustki (CF17): 5 Aug 2015, 1 ex. on Scots pine (Pinus sylvestris) at forest margin, leg. JR; Szary Dwór (CF17): 5 Aug 2015, 2 exx., undergrowth in pine forest, leg. JR.

Widely distributed in Poland (Burakowski et al. 1986). In the Baltic Coast reported from Koszalin and Zaleskie near Ustka by Lüllwitz (1915), and from Pogorzelica by Ruta et al. (2009).

\section{*Scymnus (Neopullus) limbatus Stephens, 1832}

Material: Jurata (CF56): 23 May 2015, 1 ex. shaken down from willow (Salix sp.) on a dune, leg. JR.

A species very rarely recorded in Poland. In relatively recent times reported only from Lasy Janowskie in the Sandomierska Lowland (Stączek 1996), vicinities of Poznań and Włocławek in the Wielkopolska-Kujawy Lowland (Ruta et al. 2009), Cedynia Landscape Park in the Pomeranian Lake District (Ceryngier et al. 2016b) and Warsaw in the Mazovian Lowland (Ceryngier et al. 2017). From the Baltic Coast (Koszalin and Zaleskie near Ustka) reported more than a hundred years ago by Lüllwitz $(1914,1915)$.

\section{*Scymnus (Parapullus) abietis (Paykull, 1798)}

Material: Kuźnica (CF46): 27 Jul 2013, 1 ex. shaken down from spruce (Picea abies), leg. PC.

This species feeds on adelgids (Hemiptera: Adelgidae) associated with conifers or on scale insects (Hemiptera: Coccidae) on deciduous trees (Nedvěd 2015). In older literature reported mostly from southern Poland (Burakowski et al. 1986). Recently recorded in the southern (Gren et al. 2013), central (Ruta et al. 2009, Borowski 2015, Ceryngier et al. 2016c), western (Ceryngier et al. 2016b), eastern (Jędryczkowski \& Gutowski 2014, Plewa et al. 2014a, 2014b) and north-eastern part of the country (Ceryngier et al. 2015). In the Baltic Coast found in 2007 by O. Aleksandrowicz near Świnoujście (Coleoptera Poloniae: http://baza.biomap.pl/pl/data/record/622121/default).

\section{*Scymnus (Pullus) auritus Thunberg, 1795}

Material: Pustki (CF17): 6 Sep 2014, 1 ex. on oak (Quercus sp.), leg. JR; 25 Jul 2015, 1 ex. on oak (Quercus sp.), leg. JR; Chałupy (CF47): 3 Aug 2015, 4 exx. on oak (Quercus sp.), leg. JR; 25 Sep 2015, 2 exx. on oak (Quercus sp.) in a mixed forest, leg. JR.

A species associated with deciduous trees, mainly oaks. Moderately common in Poland. In the Baltic Coast recorded by Lüllwitz (1915) in the surroundings of Koszalin and Zaleskie near Ustka. 
*Scymnus (Scymnus) rubromaculatus (Goeze, 1777)

Material: Kuźnica (CF46): 3 Aug 2015, 4 exx., grassland, leg. JR; Dębki (CF17): 23 May 2015, 1 ex. on spruce (Picea abies), leg. JR.

Relatively frequently reported from various parts of Poland, but due to its external similarity to S. femoralis (Gyllenhal, 1827), some data, especially the older ones, should be verified. In the Baltic Coast reported only by Lüllwitz (1915) from the surroundings of Koszalin and Zaleskie near Ustka.

\section{Scymnus (Scymnus) schmidti Fürsch, 1958}

Material: Dębki (CF17): 17 Aug 2014, 1 ex., pine forest, leg. JR; Władysławowo (CF37): 3 Aug 2015, 1 ex., lawn bordering pine forest, leg. JR; Wierzchucino (CF07): 4 Aug 2015, 1 ex., pine forest, leg. JR; Gdańsk Przymorze, campus of the University of Gdańsk (CF43): 5 Jul 2016, 1 ex., leg. KS.

A rare species in Poland, associated with xerothermic habitats. Recently reported from the Wielkopolska-Kujawy Lowland (Ruta et al. 2009), Mazovian Lowland (Ruta et al. 2009), Lower Silesia (Ruta et al. 2009), Małopolska Upland (Borowski 2015), Eastern Beskidy Mts (Szczepański et al. 2015), Masurian Lake District (Wigry National Park) (Ceryngier et al. 2015) and also from Karwieńskie Błota within the eastern part of the Baltic Coast (Wojas 2017).

\section{**Stethorus pusillus (Herbst, 1797)}

Material: Pustki (CF17): 25 Jul 2015, 1 ex. on oak (Quercus sp.), leg. JR; 7 Aug 2015, 2 exx. on oak (Quercus sp.) and 1 ex. on linden (Tilia sp.), leg. JR; 9 Aug 2015, 1 ex. on linden (Tilia sp.), leg. JR; Chałupy (CF37): 3 Aug 2015, 1 ex., mixed forest, leg. JR; 21 Sep 2015, 1 ex. on plum (Prunus sp.), leg. JR; Jastrzębia Góra (CF27): 22 Sep 2015, 13 exx. on maple (Acer sp.), leg. JR; Władysławowo (CF37): 19 Sep 2015, 38 exx. on maple (Acer sp.) and linden (Tilia sp.), leg. JR; 20 Sep 2015, 10 exx. on maple (Acer sp.), leg. JR; 21 Sep 2015, 1 ex. on willow (Salix sp.), leg. JR; 24 Sep 2015, 19 exx. on maple (Acer sp.) and linden (Tilia sp.), leg. JR; Gdańsk Przymorze, Ronald Reagan Park (CF46): 21 Jun 2016, 5 exx. on spindle (Euonymus sp.), leg. JR.

Specialized spider mite (Acari: Tetranychidae) predator. Although rather common in Poland and locally very abundant, it has not previously been reported from the Baltic Coast region.

\section{Calvia quindecimguttata (Fabricius, 1777)}

Material: Dębki (CF17): 8 Aug 2014, 2 exx. on a beach, leg. JR; Pustki (CF17): 7 Aug 2015, 1 ex. on birch (Betula sp.) at a forest margin, leg JR.

A rarely recorded species, associated with marshy alder forests. Newer data on its occurrence in Poland come from the Lubelska Upland (Polesie National Park) (Pietrykowska \& Stączek 2001), Mazovian Lowland (Florek et al. 2011, Godeau \& Ceryngier 2011, Ceryngier et al. 2016c), Małopolska Upland (Mokrzycki et al. 2013), Masurian Lake District (Wigry National Park) (Ceryngier et al. 2015) and Pomeranian Lake District (Cedynia Landscape Park) (Ceryngier et al. 2016b). The only previous report of this species from the Baltic Coast is that by Bubienko \& Ciepielewska (2010) from Gdańsk. 


\section{Coccinella magnifica $\mathrm{L}$. Redtenbacher, 1843}

Material: Dębki (CF17): 8 Aug 2014, 1 ex. on a beach, leg. JR; Szary Dwór (CF17): 9 Aug 2015, 1 ex., herbaceous vegetation, leg. JR; Chałupy (CF47): 3 Aug 2015, 1 ex. on a beach, leg. JR; Gdańsk-Górki Wschodnie (CF52): 17 Jun 2017, 1 ex., leg. SUG.

Facultative myrmecophile associated with ants of the genus Formica. Known from most regions of Poland, although relatively rarely reported (Burakowski et al. 1986), perhaps due to its similarity to the common C. septempunctata. In 1882 reported by Helm from Gdańsk, but in more recent times not mentioned from the eastern part of the Baltic Coast.

\section{Cynegetis impunctata (Linnaeus, 1767)}

Material: Gdańsk VII Dwór (CF42): 27 Apr 2017, 5 exx., forest clearing, leg. KS; 23 May 2017, 1 ex., forest clearing, leg. KS.

Rare herbivorous ladybird. A reduction of the membraneous wings is probably a reason for its low dispersal ability and local (although sometimes relatively abundant) occurrence. In the Baltic Coast (only in the eastern part) recorded by Bartoszyński (1937) in Puck, by Bielawski (1962) in Elblag and Tolkmicko, and recently by Napiontek \& Szawaryn (2017) in Gdańsk Oliwa. The specimens collected in this study confirm the existence of a stable population of C. impunctata in the investigated area. Other recent data from Poland refer to localities in the Pomeranian Lake District (Ceryngier et al. 2016b), Masurian Lake District (Bubienko et al. 2010), Wielkopolska-Kujawy Lowland (Ruta 2006, Renner \& Messutat 2007, Ruta et al. 2009), Lower Silesia (Greń et al. 2013), Trzebnickie Hills (Ruta et al. 2009) and Eastern Sudety Mts (Ruta et al. 2009).

\section{*Hyperaspis concolor (Suffrian, 1843)}

Material: Pustki (CF17): 11 Aug 2014, 1 ex., psammophilous grassland at the edge of pine forest, leg. JR; Gdańsk Przymorze, Ronald Reagan Park (CF46): 14 May 2017, 3 exx. on Hedera helix, leg. MN; 18 May 2017, 3 exx. near a watercourse, leg. MN.

In older literature often classified as a colour form of $H$. campestris (Herbst, 1783). Recently reported from the localities in the Pomeranian Lake District (Ceryngier et al. 2016b), Wielkopolska-Kujawy Lowland (Ruta et al. 2009, 2016), Mazovian Lowland (Borowski 2015, Szawaryn \& Hawro 2015, Kozon et al. 2016), Lower and Upper Silesia (Greń et al. 2013), Małopolska Upland (Borowski 2015), Roztocze Upland (Wojas 2017) and Sandomierska Lowland (Wojas 2017). In the Baltic Coast region reported more than a century ago from Zaleskie near Ustka (Lüllwitz 1914, 1915).

\section{* Hyperaspis reppensis (Herbst, 1783)}

Material: Krynica Morska (CF92): 28 Jul 2012, 8 exx., psammophilous grassland on a dune, leg. PC; Gdańsk Przymorze, Ronald Reagan Park (CF46): 18 May 2017, 1 ex., leg. MN.

Rare species living in xerothermic habitats. In Poland reported from few, scattered localities, including one (Koszalin) in the Baltic Coast region (Lüllwitz 1915). Recently reported from the Masurian Lake District (Ruta et al. 2009), Wielkopolska-Kujawy Lowland (Ruta et al. 2009, Renner \& Messutat 2013), Mazovian Lowland (Jędryczkowski 2010a), Podlasie Lowland (Jędryczkowski 2010b) and Białowieża Primeval Forest (Jędryczkowski \& Gutowski 2014). Some of the reports, however, may refer to other species of Hyperaspis, e.g. H. pseudopustulata Mulsant, 1853. 
*Platynaspis luteorubra (Goeze, 1777)

Material: Odargowo (CF17): 16 Aug 2014, 2 exx. on spruces (Picea abies), leg. JR; Pustki (CF17): 11 Aug 2014, 3 exx. (2 imagines, 1 larva), sorrel (Rumex sp.) on a grassland, leg. JR; 24 Jul 2015, 1 ex. (larva), grassland, leg. JR; 26 Jul 2015, 2 ex. (larvae) on oak (Quercus sp.), leg. JR; 26 Jul 2015, 11 exx., psammophilous grassland, leg. JR; 7 Aug 2015, 4 exx., grassland, leg. JR; Chłapowo (CF37): 20 May 2017, 1 ex., xerothermic grassland, leg. KS.

A species preferring warm and sunny habitats. Widely distributed in Poland, but relatively rarely recorded (Burakowski et al. 1986). Within the Baltic Coast, reported by Lüllwitz (1915) from Koszalin and more recently by O. Aleksandrowicz from Wiklino near Słupsk (Coleoptera Poloniae: http://baza.biomap.pl/pl/data/record/659443/default).

\section{DISCUSSION}

Of the 44 species of Coccinellidae recorded in the eastern part of the Baltic Coast in this study, 10 have not previously been reported from this region. On the other hand, we failed to catch the following 12 species previously reported by other authors: Parexochomus nigromaculatus (Gdańsk-Oliwa - Lentz 1866, 1879; Gdynia-Kępa Redłowska - Konopko et al. 2017), Rhyzobius litura (Fabricius, 1787) (Gdańsk environs - Helm 1880), Scymnus apetzi Mulsant, 1846 (Władysławowo - Węgrzecki 1932), S. interruptus (Goeze, 1777) (Gdańsk Lenz 1879), Ceratomegilla alpina (Chałupy - Śliwiński \& Kowalczyk 1995), C. undecimnotata (vicinity of Żarnowiec Lake - Lentz 1879), Coccinella hieroglyphica Linnaeus, 1758 (Władysławowo - Węgrzecki 1932; Hel - Bielawski 1959), C. undecimpunctata Linnaeus, 1758 (Hel Peninsula - Bartoszyński 1937), Oenopia conglobata (Linnaeus, 1758) (Hel Peninsula - Brischke 1888, Węgrzecki 1932), Sospita vigintiguttata (Linnaeus, 1758) (Gdańsk - Lentz 1879, Helm 1880), Vibidia duodecimguttata (Poda, 1761) (Gdańsk - Horion 1961) and Novius cruentatus (Mulsant, 1846) (Gdańsk - Zebe 1853, Lentz 1879). Of these species, one (O. conglobata) is common in Poland, and several others (S. interruptus, C. hieroglyphica, C. undecimpunctata, S. vigintiguttata, V. duodecimguttata) are relatively rare, but their presence in the investigated region is unquestionable. Confirmation of the occurrence in the Baltic Coast of some of the other previously recorded species, such as S. apetzi, C. undecimnotata and C. alpina, will be rather difficult, taking the general pattern of their distribution into account. Scymnus apetzi and C. undecimnotata occur mainly in southern Europe and south-western Asia and C. alpina is a European montane species (Kovár 2007). The former has not been recently reported from Poland and the older reports probably refer to S. suffrianioides apetzoides Capra et Fürsch, 1967 (Burakowski et al. 1986), while both species of Ceratomegilla are sporadically recorded in southern Poland (Ruta et al. 2009, Greń et al. 2013, Wojas 2017). The presence of $R$. litura in the investigated area should be confirmed by new findings, because previous authors regularly misidentified the much more common $R$. chrysomeloides as $R$. litura (Bielawski 1955).

Although the communities of Coccinellidae associated with different habitat types were clearly different, they were usually dominated by the species very common in Poland. An exception was the community found on the conifers, where the most abundant was $R$. chrysomeloides, a species relatively rarely recorded in Poland, and the next most common was Scymnus suturalis Thunberg, 1795. Interestingly, recent studies in the Cedynia Landscape Park (NW Poland) (Ceryngier et al. 2016b) showed a very similar species composition of Coccinellidae on conifers, with the contribution of each, $R$. chrysomeloides and $S$. suturalis, exceeding $20 \%$. The high numbers of $C$. septempunctata observed by us on seaside beaches seems to be a typical phenomenon, reported also by other researchers (Jędrzejczak 2002, Wolender \& Zych 2007, Bubienko \& Ciepielewska 2010). 
The contribution of the invasive $H$. axyridis to all ladybirds recorded in the study (13\%) can be regarded as relatively low compared to the $20 \%$ contribution of this species recorded recently (2014-2015) in north-western Poland (Cedynia Landscape Park) (Ceryngier et al. 2016b). The difference remains clear also when the contribution of $H$. axyridis in its preferred habitat type (deciduous trees and shrubs) is compared (24\% in the eastern part of Baltic Coast and 31\% in the Cedynia Landscape Park). On the other hand, in the survey conducted in 20142016 in north-eastern Poland (Wigry National Park) H. axyridis constituted less than $1 \%$ of the recorded ladybirds (Ceryngier et al. 2015, 2016a). As H. axyridis is usually more abundant in urban than natural and semi-natural habitats (Adriaens et al. 2008), one may suppose that the observed differences are linked to the degree of urbanization of individual regions. While urbanized areas are indeed practically lacking in the Wigry National Park, the region with the highest proportion of $H$. axyridis (Cedynia Landscape Park) is also a mosaic of forest and agricultural areas, with only a few villages and small towns. In contrast, the eastern part of the Baltic Coast includes a large agglomeration of Gdańsk, Gdynia and Sopot and many smaller resort towns. Thus, the decreasing frequency of $H$. axyridis from the west to the east can be better explained in terms of the direction this species has colonized the territory of Poland (Przewoźny et al. 2007, Ceryngier 2008) and probably also the effect of climatic constraints. North-eastern peripheries of Poland lie close to the current edge of the $H$. axyridis invasive range in Europe. In the more northern and eastern areas in Lithuania and the Kaliningrad region of Russia $H$. axyridis is recorded sporadically (Ukrainsky \& OrlovaBienkowskaja 2014, Havelka et al. 2015).

To conclude, our survey revealed a moderately rich fauna of Coccinellidae in the eastern part of the Baltic Coast. In a short survey recently carried out in Cedynia Landscape Park (Ceryngier et al. 2016b), 50 species were recorded, i.e. six more than in this study. Further faunistic exploration would probably enable the discovery in the Baltic Coast region of several other ladybird species, such as Scymnus ferrugatus (Moll, 1785) or Oenopia impustulata (Linnaeus, 1767).

\section{ACKNOWLEDGEMENTS}

We would like to thank Paweł Boniecki, Grażyna Butrykowska, Jan Gleba, Marlena Napiontek, Izabella Olejniczak and Mateusz Romanowski for their help in the field works and Wojciech T. Szczepański and two anonymous reviewers for their valuable comments on the earlier versions of this paper.

\section{REFERENCES}

Adriaens T., SAn Martin y Gomez G. \& MAEs D. 2008. Invasion history, habitat preferences and phenology of the invasive ladybird Harmonia axyridis in Belgium. BioControl 53: 69-88.

BARTOSZYŃSKI A. 1937. Coleopterologische Studien an der Polnischen Ostseeküste. Fortsetzung der Erforschung der Käferfauna der Halbinsel Hel. Fragmenta Faunistica Musei Zoologici Polonici 3: 69-80. [In Polish with German summary]

BIELAWSKI R. 1955. Morphological and systematical studies on Polish species of the genus Rhyzobius Stephens, 1831 (Coleoptera, Coccinellidae). Annales Zoologici 16: 29-50.

BIELAWSKI R. 1958. A revision of the genus Anisosticta DUPONCH., with description of a new species from Siberia (Coleoptera, Coccinellidae). Annales Zoologici 17: 91-112.

BIELAwSKI R. 1959. Chrząszcze - Coleoptera, Biedronki - Coccinellidae. Klucze do Oznaczania Owadów Polski 19: $1-92$.

BIELAWSKI R. 1961. Die in einem Krautpflanzenverein und in einer Kieferschonung in Warszawa-Bielany auftretenden Coccinellidae (Coleoptera). Fragmenta Faunistica 8: 485-525. [In Polish with German and Russian summary].

Bielawski R. 1962. Materialien zur Kenntnis der Coccinellidae Polens. I (Coleoptera). Polskie Pismo Entomologiczne / Bulletin Entomologique de Pologne 32: 191-205. [In Polish] 
BIELAwSKI R. 1971. Marienkäfer (Coleoptera, Coccinellidae) vom Bieszczady-Gebirge. Fragmenta Faunistica 17: 273-296. [In Polish with Russian and German summaries]

BIELAWSKI R. 1978. Die Marienkäfer (Coleoptera, Coccinellidae) der Pieninen. Fragmenta Faunistica 22: 337-357. [In Polish with Russian and German summary].

Bloch-Orlowska J., AfranowicZ-Cieślak R., ŻóŁKoś K., KuKWa M., Kaczorowska E., Gerstmann E., ŚCIBORSKi M., MeIsSner W., Pleskot I. \& MikoŚ J. 2015. Nature of the 'Helskie Wydmy' reserve (northern Poland). Acta Botanica Cassubica, Monographiae 5, 1-135. [In Polish with English abstract].

Bodzon K. \& CERYNGier P. 2016. Winter and early spring assemblages of ladybird beetles (Coleoptera: Coccinellidae) in two forest habitats in suburban area of Warsaw, central Poland. Studia Ecologiae et Bioethicae 14: 115-129.

BorowSKI J. 2015: Beetles (Coleoptera) of the Rogów region. Part II - ladybirds (Coccinellidae). International Letters of Natural Sciences 7: 90-101; DOI: 10.18052/www.scipress.com/ILNS.34.90

BRISChKE C. G. A. 1888. Bericht über eine Excursion nach Hela während des Juli 1887. Schriften der Naturforschenden Gesellschaft in Danzig 7 (1): 42-64.

BRISCHKE C. G. A. 1891. Bericht über eine zweite Excursion nach Steegen im Jahre 1889. Schriften der Naturforschenden Gesellschaft in Danzig 7 (4): 50-74.

BuBIENKO K. \& CIEPIELEWSKA D. 2010. Ladybirds /Coleoptera, Coccinellidae/ on the beaches of Gdańsk. Aphids and Other Hemipterous Insects 16: 119-125.

BubienKo K., KosewsKa A. \& CiepielewsKa D. 2010: Ladybirds /Coleoptera, Coccinellidae/ of midfield thickets. Aphids and Other Hemipterous Insects 16: 107-117.

Burakowski B., MroczKowsKi M. \& StefańSKa J. 1986. Chrząszcze - Coleoptera. Cucujoidea, część 2. Katalog fauny Polski 23, 13: 1-278.

BURZYŃSKI J. 1971. Badania entomofauny drzewostanów sosnowych na terenach wydmowych. Prace Instytutu Badawczego Leśnictwa 404: 3-90.

CERYNGIER P. 2008. Ladybird conquers the world. Academia 3 (19): 34-36.

CERyngier P., KrzysztofiaK A. \& Romanowski J. 2015. Ladybird beetles (Coleoptera: Coccinellidae) of Wigry National Park. Parki Narodowe i Rezerwaty Przyrody 34 (1): 13-24. [In Polish with English abstract].

Ceryngier P., Krzysztofiak A. \& RomanowsKi J. 2016a. New data on ladybird beetles (Coleoptera: Coccinellidae) of Wigry National Park. Kulon 21: 69-82. [In Polish with English summary].

CERYNGIER P., ROMANOWSKi J. \& ROMANOWSKi M. 2016b. Ladybird beetles (Coleoptera: Coccinellidae) of Cedynia Landscape Park. Wiadomości Entomologiczne 35: 41-58. [In Polish with English abstract]

Ceryngier P., Romanowski J. \& Romanowski M. 2016c. Biedronkowate (Coleoptera: Coccinellidae) Parku Skaryszewskiego. In: J. RoMANOWSKI (ed.), Park Skaryszewski w Warszawie - przyroda i użytkowanie, pp. 177186. Wydawnictwo UKSW, Warszawa, 262 pp.

Ceryngier P., Romanowski J., Bodzon K., PIOTROWSKa M. \& SitARSKA D. 2017. Ladybird beetle (Coleoptera: Coccinellidae) communities on the floodplain of the Vistula River in Warsaw. Kulon 22: 117-123. [In Polish with English summary]

Czechowska W. \& Bielawski R. 1981. Coccinellids (Coleoptera, Coccinellidae) of Warsaw and Mazovia. Memorabilia Zoologica 34: 181-197.

EICHLER W. 1914. Przyczynek do tęgopokrywych Ojcowa. Pamiętnik Fizyograficzny 22: 138-149.

ENDERLEIN G. 1908. Biologisch-faunistische Moor- und Dünen-Studien. Westpreussischen Botanisch-Zoologischen Vereins 30: 54-238.

Escalona H. E., ZWick A., Li H. S., Li J., WANG X., PANG H., Hartley D., Jermin L.S., NedVĚD O., MisOF B., NieHUis O., ŚLIPIŃSKI A. \& TOMASZEWSKA W. 2017. Molecular phylogeny reveals food plasticity in the evolution of true ladybird beetles (Coleoptera: Coccinellidae: Coccinellini). BMC Evolutionary Biology 17: 151, 11 pp.; DOI: 10.1186/s12862-017-1002-3

FloReK K., TRAgARZ J. \& CERYNGIER P. 2011. Species composition and diets of ladybird beetles (Coleoptera: Coccinellidae) associated with black alder (Alnus glutinosa (L.) Gaertner) in a marshy forest. Aphids and Other Hemipterous Insects 17: 165-174.

FÜRSCH H., KREISSL E. \& CAPRA F. 1967. Revision einiger europäischer Scymnus (s.str.)-Arten (Col., Coccinellidae). Mitteilungen der Abteilung für Zoologie und Botanik an Landesmuseum "Joanneum" in Graz 28: 207-259.

GodeAu J.-F. \& CERYNGIER P. 2011. Notes on the overwintering of marshy forest ladybirds in Poland and on the colour change in Sospita vigintiguttata throughout the winter. Harmonia - Coccinelles du monde 6: 20-24.

Greń C., SzOŁTYS H., Grzywocz J. \& KróLIK R. 2013. Beetles (Coleoptera) of the Lower and Upper Silesia - the current state of knowledge and new faunistic data: ladybird beetles (Coccinellidae). Acta entomologica silesiana 21: 31-52. [In Polish with English abstract]

HAVELKA J., DANILOV J., RAKAUSKAS R. \& FERENCA R. 2015. Barcoding data of the first Harmonia axyridis (Pallas, 1773) invaders in Lithuania. Baltic Journal of Coleopterology 15: 99-105.

HELM O. 1880. Schriften der Naturforschenden Gesellschaft in Danzig 4 (4): 56-57.

HELM O. 1882. Schriften der Naturforschenden Gesellschaft in Danzig 5 (3): 22-23. 
HoRION A. 1961. Faunistik der Mitteleuropäischen Käfer. Band VIII: Clavicornia 2. Teil (Thorictidae bis Cisidae), Teredilia, Coccinellidae. Überlingen-Bodensee, XVI + 375 pp.

JĘDRYCZKOWSKI W. B. 2010a. Ecological aspects of distribution of predatory beetles (Coleoptera: Coccinellidae) in Warsaw urban area. In: Dyguś K. H., MEDIOKRITSKI Y. L. (eds), Ekologiczne problemy XXI wieku, pp. 235240. Wyższa Szkoła Ekologii i Zarządzania, Warszawa, 328 pp. [In Polish with English summary]

JĘDRYCZKOWSKI W. B. 2010b. Biodiversity of the predatory beetles (Coleoptera) in the valley of Bug river in Poland. In: DyGuŚ K. H. (ed.), Natural Environment of Transfrontier River Catchments in Poland and Ukraine, pp. 97104. Wyższa Szkoła Ekologii i Zarządzania, Warszawa, 124 pp..

JĘDRYCZKOWSKI W.B. \& GUTOWSKI J.M. 2014. Coccinellidae(Coleoptera) of Białowieża Primeval Forest. Wiadomości Entomologiczne 33: 200-213. [In Polish with English abstract]

JĘDRZEJCZAK M. F. 2002. Stranded Zostera marina L. vs wrack fauna community interactions on a Baltic sandy beach (Hel, Poland): a short-term pilot study. Part II. Driftline effects of succession changes and colonisation of beach fauna. Oceanologia 44: 367-387.

KLEINE R. 1940. Übersicht über die in Pommern gefundenen Käfer, die im Verzeichnis von Albert Lüllwitz nicht enthalten sind. Nebst einigen Bemerkungen über schon genannte Arten. Dohrniana 19: 3-28.

Konopko D., KowalczyK J.K., Komosiński K., SienKiewicz P., AleKsandrowicz O., PrZewoźny M., KONWERSKi S., MOCARSKi Z., LASECKI R. \& BUCHHOlZ L. 2017. Materiały Materials to the knowledge of beetles (Insecta: Coleoptera) of the Kępa Redłowska in Gdynia. Przegląd Przyrodniczy 28 (3): 45-72. [In Polish with English abstract]

KONOPKO D. \& WILGA M.S. 2014. A contribution to the staudy [sic!] of coleoptera in Trójmiejski Landscape Park. Przegląd Przyrodniczy 25(1): 64-71. [In Polish with English abstract]

KovÁř I. 2007. Family Coccinellidae Latreille, 1807. In: LÖBL I., SMETANA A. (eds), Catalogue of Palaearctic Coleoptera, Vol. 4, pp. 568-631. Apollo Books, Stenstrup, 935 pp.

KOzOn E., CERYNGIER P. \& ROMANOWSKI J. 2016. Overwintering of ladybird beetles (Coleoptera: Coccinellidae) in the suburban zone of Warsaw. Wiadomości Entomologiczne 35: 82-90. [In Polish with English abstract]

KRÓLIK R. 2006: Confirmation of the occurrence of Clitostethus arcuatus (P. Rossi, 1794) (Coleoptera: Coccinellidae). Wiadomości Entomologiczne 52: 126. [In Polish]

LENTZ F. L. 1866. Zweiter Nachtrag zum neuen Verzeichniss der Preussischen Käfer, Königsberg 1857. Schriften der Königlichen Physicalisch-Ökonomischen Gesellschaft zu Königsberg 7: 85-98.

LENTZ F. L. 1879. Catalog der preussischen Käfer. Beiträge zur Naturkunde Preussens 4, II + 64 pp.

LETZNER K. 1874. Nachtrage zu seinem Verzeichniss der Kafer Schlesiens. Jahres-Bericht der Schlesischen Gesellschaft für vaterländische Cultur 51: 184-188.

LÜLlwITZ A. 1914. Beitrag zur Kenntnis der Käferfauna Pommerns. Deutsche Entomologische Zeitschrift 4: $396-405$.

LÜLLWITZ A. 1915. Verzeichnis der im Regierungsbezirk Köslin aufgefundenen Käfer. Stettiner Entomologische Zeitung 76: 205-264.

MoKRZYCKI T., BOROWSKi J., BYK A. \& RUTKIEWICZ A. 2013. Valorisation of the ecosystems of Forest Promotional Complex "Lasy Spalsko-Rogowskie" based on the structure of beetle (Coleoptera) assemblages inhabiting stumps. Studia i Materiały CEPL w Rogowie 35(2): 48-81. [In Polish with English abstract]

NAPIONTEK M. \& SZAWARYN K. 2017. Confirmation of the occurrence of Cynegetis impunctata (LinNAEUS, 1767) (Coleoptera: Coccinellidae) in Pomerania. Acta entomologica silesiana 25: 1-2. [In Polish]

NEDVĚD O. 2015. Ladybird beetles (Coccinellidae) of Central Europe. Academia, Praha, 303 pp.

PAWŁowsKi J. 1966. The beetles (Coleoptera) collected on the beach near Pobierowo in Western Pomerania. Acta Zoologica Cracoviensia 11: 387-395. [In Polish with Russian and English summary]

PietRYKowsKa E. \& STĄCZEK Z. 2001. Biedronkowate (Coleoptera: Coccinellidae) Poleskiego Parku Narodowego i okolic. Część I. Parki Narodowe i Rezerwaty Przyrody 20(1): 55-62.

PleWA R., HILSZCZAŃSKi J., JAWORSKI T. \& SIERPIŃSKI A. 2014b. New and rare saproxylic beetles (Coleoptera) of eastern Poland. Wiadomości Entomologiczne 33: 85-96. [In Polish with English abstract]

PlewA R., JAWORSKI T. \& HilSZCZAŃSKi J. 2014a: Dead wood and community structure of saproxylic beetles (Coleoptera) in oak stands. Studia i Materiały CEPL w Rogowie 41(4): 279-299. [In Polish with English abstract]

PRZEWoźNY M., BARŁożEK T. \& BUNALSKi M. 2007. Harmonia axyridis (PALLAS, 1773) (Coleoptera: Coccinellidae) new species of ladybird beetle for Polish fauna. Polish Journal of Entomology 76: 177-182.

RENNER K. \& MESSUTAT J. 2007. Untersuchungen zur Käferfauna der Umgebung von Skwierzyna im westlichen Polen (Wielkopolska). Coleo 8: 16-20.

RENNER K. \& MESSUTAT J. 2013. Untersuchungen zur Käferfauna der Umgebung von Skwierzyna im westlichen Polen (Wielkopolska) II. Coleo 14: 1-6.

RuTA R. 2006. Chrząszcze (Insecta: Coleoptera) kserotermicznych Wzgórz Byszewickich w Dolinie Noteci. Nowy Pamiętnik Fizjograficzny 5 (1-2): 49-106.

Ruta R., JAŁoszyŃSki P., Konwerski S., MAJewSKi T. \& BARŁożeK T. 2009. Ladybird beetles (Coleoptera: Coccinellidae) of Poland. Part 1. New faunistic data. Wiadomości Entomologiczne 28: 91-112. [In Polish with English abstract]. 
Ruta R., Orzechowski R., Aleksandrowicz O., Borowski J., Buchholz L., Komosiński K., Lubecki K. \& PRZEWOŹNY M. 2016. Beetles (Insecta: Coleoptera) of Gryżyński Landscape Park. Przegląd Przyrodniczy 27 (2): 28-62. [In Polish with English abstract]

SEAgo, A.E., Giorgi J. A., Li J. \& ŚLIPIŃSKi A. 2011. Phylogeny, classification and evolution of ladybird beetles (Coleoptera: Coccinellidae) based on simultaneous analysis of molecular and morphological data. Molecular Phylogenetics and Evolution 60: 137-151. DOI: 10.1016/j.ympev.2011.03.015

STĄCZEK Z. 1996. Preliminary studies on Coccinellidae of the Landscape Park "Janów Forests”. In: RADWAN S., SAŁATA B., SzUnKE Z. (eds), Walory przyrodnicze Parku Krajobrazowego „Lasy Janowskie”, pp. 81-82. Wydawnictwo UMCS, Lublin, 84 pp. [In Polish with English summary]

SZAWARYN K. \& HAWRO V. 2015. Hyperaspis concolor (Suffrian, 1843) (Coleoptera: Coccinellidae) in central Poland. Wiadomości Entomologiczne 34: 50-51. [In Polish]

SZCZEPAŃSKi W.T., TASZAKOWSKI A., KARPIŃSKI L. \& KUBUSIAK A. 2015. New data on the distribution of ladybird beetles (Coleoptera: Coccinellidae) in the Eastern Beskid Mts. Nature Journal 48: 24-33.

ŚLIPIŃSKI A. 2007. Australian Ladybird Beetles (Coleoptera: Coccinellidae): their biology and classification. CSIRO Publishing, Canberra, 306 pp.

ŚLIWIŃSKI Z. \& KOWALCZYK J.K. 1995. New localities of interesting beetle species (Coleoptera) in Poland. Wiadomości Entomologiczne 14: 187. [In Polish]

UKRAinSKY M.S. \& ORLOVA-BIENKOWSKAJA M.JA. 2014. Expansion of Harmonia axyridis Pallas (Coleoptera: Coccinellidae) to European Russia and adjacent regions. Biological Invasions 16: 1003-1008. DOI: 10.1007/s10530-013-0571-3

WĘGRZECKI M. 1932. Koleopterologische Studien am der Ostseekünste. I. Bisherige Ergebnisse der Erforschung der Käferfauna der Halbinsel Hel. Fragmenta Faunistica 1: 465-505. [In Polish with German summary].

WojAS T. 2017. New records of rare species of ladybirds (Coleoptera: Coccinellidae) in Poland. Wiadomości Entomologiczne 36: 179-181. [In Polish]

WOLENDER M. \& ZYCH A. 2007. Beetles (Coleoptera) from seaside beach and dunes in the regions of Świnoujście, Międzyzdroje and Wisełka (Poland) located along the southern coast of the Baltic Sea. Baltic Journal of Coleopterology 7: 61-71.

ZEBE G. 1853. Synopsis der bisher in Deutschland aufgefundenen Coleoptera. Entomologische Zeitung 14: 33-182.

\section{STRESZCZENIE}

\section{[Nowe dane o rozmieszczeniu biedronkowatych (Coleoptera: Coccinellidae) we wschodniej części Pobrzeża Bałtyku]}

Biedronki, za sprawą kilku pospolitych gatunków, to dość dobrze rozpoznawalna grupa chrząszczy. Mimo to wiedza na temat rozmieszczenia poszczególnych gatunków na terenie kraju jest dość fragmentaryczna. W niniejszej pracy prezentujemy najnowsze dane o rozmieszczeniu Coccinellidae we wschodniej części Pobrzeża Bałtyku, od Mierzei Wiślanej po okolice miejscowości Białogóra. Ogółem, w latach 2012-2017 zarejestrowaliśmy na omawianym terenie 4471 osobników Coccinellidae należących do 44 gatunków. Gatunkiem najczęściej odławianym była Coccinella septempunctata, liczne były również inwazyjna Harmonia axyridis, Propylea quatuordecimpunctata, Psyllobora vigintiduopunctata, Rhyzobius chrysomeloides i Scymnus suturalis. Niektóre z odnotowanych biedronek są wykazywane rzadko lub zostały stwierdzone po raz pierwszy na badanym obszarze. Należą do nich: Calvia quindecimguttata, Hyperaspis concolor, H. reppensis, Platynaspis luteorubra, Scymnus abietis, S. limbatus, S. rubromaculatus. Dwa gatunki, Clitostethus arcuatus i Stethorus pusillus, wykazano po raz pierwszy z z terenu Pobrzeża Bałtyku. 